\title{
Infant and Child Burial Rites in Roman Britain: a Study from East Yorkshire
}

\author{
By MARTIN MILLETT and REBECCA GOWLAND
}

\begin{abstract}
The discovery of infant burials on excavated domestic sites in Roman Britain is fairly common but in the past these burials have often been dismissed as a product of unceremonious disposal. There is a growing literature which considers the phenomenon, but it has been dominated by debates around the suggestion that these burials provide evidence for infanticide, with a focus on the osteological evidence for and against this hypothesis. There has been less systematic consideration of the archaeological context of such burials. In this paper we examine the excavated evidence of two large groups of such burials from sites in East Yorkshire which demonstrate that the burial of neonatal infants followed a careful age-specific funerary rite. We suggest that this conclusion further undermines the widespread assumption that infants were disposed of without ceremony and as a result of infanticide.
\end{abstract}

Keywords: Hayton; Shiptonthorpe; infant burial; cremation burial; Roman cemeteries; roadside settlement

\section{INTRODUCTION: THE HYPOTHESIS OF INFANTICIDE ${ }^{1}$}

I nfant burials have been widely discovered on settlement sites in Roman Britain but there has hitherto been little attempt to understand them contextually. We contend that they deserve careful study and analysis as an understanding of the rites surrounding their burial has the potential to contribute to a fuller and broader knowledge of social relations within Roman Britain. Previous discussion of infant burial in Roman Britain has, however, focused either on the idea that neonatal deaths were not mourned and hence their bodies were unceremoniously disposed of in rubbish deposits, or that groups of such burials represent evidence for the deliberate disposal of unwanted infants who had been killed at birth. There has been little systematic evaluation of the first idea, while debates have instead centred on the possible practice of infanticide. Evidence in support of this hypothesis has been presented in a series of papers by Mays and his associates, which focus on the fact that an unexpectedly high proportion of these infants died at around the time of birth, at the age of 38-42 gestational

1 Note that in this paper we use the term infant to refer to those under one year of age, neonates for those aged 38-40 weeks of gestation, and premature for those under 38 weeks of gestation. 
weeks. $^{2}$ This idea is based on empirical observation of skeletal remains in addition to parallels drawn from excavations at Ashkelon in Israel, which supposedly demonstrate the practice of infanticide elsewhere in the Roman Empire. ${ }^{3}$ More recently, Mays' studies have focused on the much-discussed assemblage of infant burials excavated at Yewden (Hambledon, Bucks.) in the 1920s. ${ }^{4}$ Mays' overall conclusion is that infanticide was widely practised in Roman Britain and elsewhere across the Empire - with a likely bias towards the killing of females. The publicity surrounding the publication of the Yewden material ${ }^{5}$ has given much emphasis to interpretations which move far beyond any credible reading of the evidence with the suggestion that the site was a brothel, ${ }^{6}$ echoing the interpretation of the Ashkelon site.

A number of authors have already questioned Mays' conclusions based on both scientific method and a more careful reading of the ancient textual evidence. ${ }^{7}$ First, it has been shown that the method used for the original analysis probably overemphasised the tightness of the peak in the age distribution around the time of birth (FIG. 1). ${ }^{8}$ Second, it has been noted that the textual evidence Mays relies upon does not support any simple model of infanticide. Rather, the exposure of infants was a more complex and nuanced phenomenon, with many infants who were rejected by their parents at birth likely to have been adopted by others. ${ }^{9}$ Furthermore, it is noted that any such infants who died following exposure after birth are most unlikely to have been buried in any archaeologically recoverable manner. ${ }^{10}$

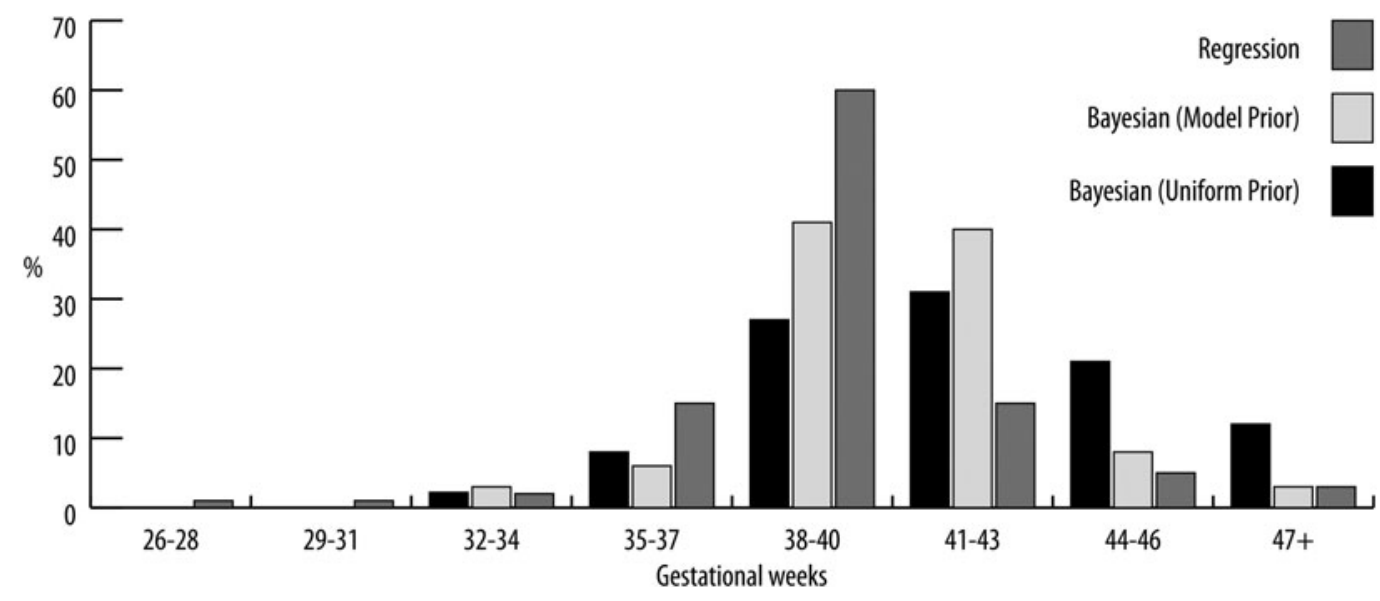

FIG. 1. Comparison of the infant age-at-death distributions obtained using regression versus Bayesian methods of analysis $(\mathrm{n}=164)$. (Drawn by Lacey M. Wallace after Gowland and Chamberlain 2002)

In addition to these points of criticism, we may note that reliance on archaeological parallels from the other end of the Roman Empire is probably unwise since there is very considerable

e.g. Mays 1993; 2000; 2003; Mays and Faerman 2001; Mays and Eyers 2011.

Smith and Kahila 1992.

Cocks 1921; Mays and Eyers 2011; Eyers 2011; Mays et al. 2012; Hassan et al. 2014.

e.g. http://www.bbc.co.uk/news/10384460

Eyers 2011, 278; cf. British Archaeology 121 (November/December 2011), 66.

Gowland 2001; Gowland and Chamberlain 2002; Moore 2009; Gowland et al. 2014.

Gowland and Chamberlain 2002; but disputed by Mays 2003.

Boswell 1984; 1998; Grubbs 2010.

Gowland et al. 2014. 
evidence that religious beliefs and burial practices showed significant regional and interprovincial variation, not to mention the issues of change through time. ${ }^{11}$ The evidence from Ashkelon in Israel is particularly problematic. First, the publication of the excavated evidence cited by Mays does not provide any precise stratigraphic or contextual evidence for the infants discussed beyond the fact that they were found in a sewer, so the excavators' conclusion that they were a product of infanticide is unsupported and relies on a questionable and intuitive assertion. ${ }^{12}$ Second, the cultural context is one where there is very specific evidence for the special treatment of dead infants arguably associated with long traditions of child sacrifice. ${ }^{13}$ Irrespective of how the Ashkelon evidence might be interpreted, there can be no question that Roman Palestine is contextually very different from Roman Britain.

Finally, we may note that the previous suggestion that infanticide was directed towards females seems to have been undermined by the ancient DNA studies of the biological sex of these infants. Contrary to expectations, the ancient DNA study of the infants from Ashkelon revealed an excess of males over females, ${ }^{14}$ while the study of the Yewden infants demonstrated no significant sex-bias. For Ashkelon, sex was established for only 19 out of the 43 infants sampled (yielding 14 males versus 5 females), while at Yewden only 12 out of the 33 infants sampled yielded a sex (yielding 7 females versus 5 males). ${ }^{15}$ Given the small proportion of the total samples that yielded a biological sex in each of these studies, no definitive conclusions can be drawn.

As a consequence of this body of work, infant burials in Roman Britain are now often accepted as representing victims of infanticide. This is despite the premise being repeatedly contested by authors who have instead highlighted the fact that careful choices appear to have been made in terms of age-at-death and the location of these burials. ${ }^{16}$ As Eleanor Scott states: 'if we can get past the Victorian obsession with baby-dropping, we might be able to detect complex patterns of ritual and ideological treatment of deceased infants...' ${ }^{17}$ With this in mind, this study aims to provide a detailed examination of two large samples of infant burials from Romano-British sites in East Yorkshire.

\section{AN ALTERNATIVE APPROACH}

A different explanation for the widespread occurrence of infant burials lies in the likelihood of high infant mortality in Roman Britain and, especially, a peak in deaths around the time of birth. Natural infant mortality statistics demonstrate that this pattern is the norm and is likely to have also been the case in Roman Britain. ${ }^{18}$ However, it is well known that high frequencies of neonatal infants tend not to be recorded in excavated cemeteries from this period, or indeed cemeteries of other periods. There are a few exceptions to this rule, including Poundbury, Dorset, ${ }^{19}$ but even here neonatal infants are still under-represented given the large size of the cemetery population. The absence of the expected number of infants and children from cemeteries suggests that formal burial within such contexts was not the universal practice for all age and sex groups in Roman Britain. ${ }^{20}$ One must, of course, also consider taphonomic

e.g. Struck 1993; Pearce et al. 2001.

Stager et al. 2008, especially p. 293.

e.g. Aubet 1993, 208-12; Crawley-Quinn 2011, 390

Faerman et al. 1997.

Hassan et al. 2014.

e.g. Struck 1993; Scott 1999; 2001; Gowland 2001; Pearce 2001; Moore 2009; Gowland et al. 2014.

Scott 1997, 7-8.

Pearce 2001.

Farwell and Molleson 1993.

Pearce 2013, 13-26. 
factors regarding the poorer preservation of infant bones and recovery biases, ${ }^{21}$ but these do not provide a complete explanation given the high frequency of these age-groups excavated from non-cemetery sites. ${ }^{22}$ It seems clear that there must have been a variety of different funerary rites and these may have been dependent upon aspects of social identity such as age, gender and ethnicity. The question then arises as to how and where other members of the population were disposed of at death.

Part of the answer to this question must lie in the occurrence of infant burials in settlement sites which, as we have noted, is a widespread phenomenon. However, in an infant population with natural causes of death we would expect there to be a range of ages-at-death represented, with a representative proportion of premature infants, as well as a number who survived for a few months after birth, in addition to those who died at birth. The studies by Mays cited above indicate that there are fewer premature and older infants than we should expect, hence his conclusion that the peak at full-term is not a natural phenomenon. The re-evaluation by Gowland and Chamberlain ${ }^{23}$ argued for the presence of a broader range of ages-at-death, though a neonatal peak was still present, albeit less pronounced (FIG. 1). If it is not a product of infanticide as Mays suggests, then why is there this bias towards neonatal infants in the archaeological record?

As Mays and Eyers stated in discussing the Yewden burials:

A further possibility is that for some reason, the excavated area at Hambledon was used for burials of mainly full-term infants, with most slightly younger or older ones being buried elsewhere. The Hambledon perinatal age distribution resembles those produced from other Roman sites in Britain (Mays 1993), so for this to be an explanation it would have to apply more generally, with interment of pre-term foetuses and infants dying in the first few weeks of life in ways which have left no trace archaeologically. We know of no evidence that this sort of burial selection process was carried out in the Roman World. ${ }^{24}$

It is our contention that evidence for such a pattern does exist and has been found on sites in East Yorkshire, initially noted at Shiptonthorpe, ${ }^{25}$ and now reinforced by further evidence from Hayton (FIG. 2). ${ }^{26}$ This evidence may be summarised as follows.

\section{PATTERNS IN THE EVIDENCE: SHIPTONTHORPE}

Excavations on the Roman roadside settlement at Shiptonthorpe between 1985 and 1991 revealed a total of 22 infant burials plus five individuals who were cremated. The inhumations were published by J. Langston with the cremated remains analysed by M. Marlowe and L.C. Winter. ${ }^{27}$ The largest group of infant burials came from Trench 3 which explored a single domestic unit that was occupied from the second to the fourth centuries and it is here that we have clear evidence for their spatial patterning. Langston's analysis of the age-at-death of the infants (Table 1; FIG. 3) showed that the vast majority died in the period around full-term (38-40 gestational weeks), thereby fitting in with the pattern discussed by Mays. However, an analysis of the distribution of the 11 burials of Phases 4 and 5 (early to mid-fourth century) in

Guy et al. 1997.

Buckberry 2000.

Gowland and Chamberlain 2002.

Mays and Eyers 2011, 1937.

Millett 2006.

Halkon et al. in press.

Millett 2006, 251-7. The infant ages at death were calculated using the technique described by Scheuer et al.

1980, which estimates age from limb bone length by linear regression. 


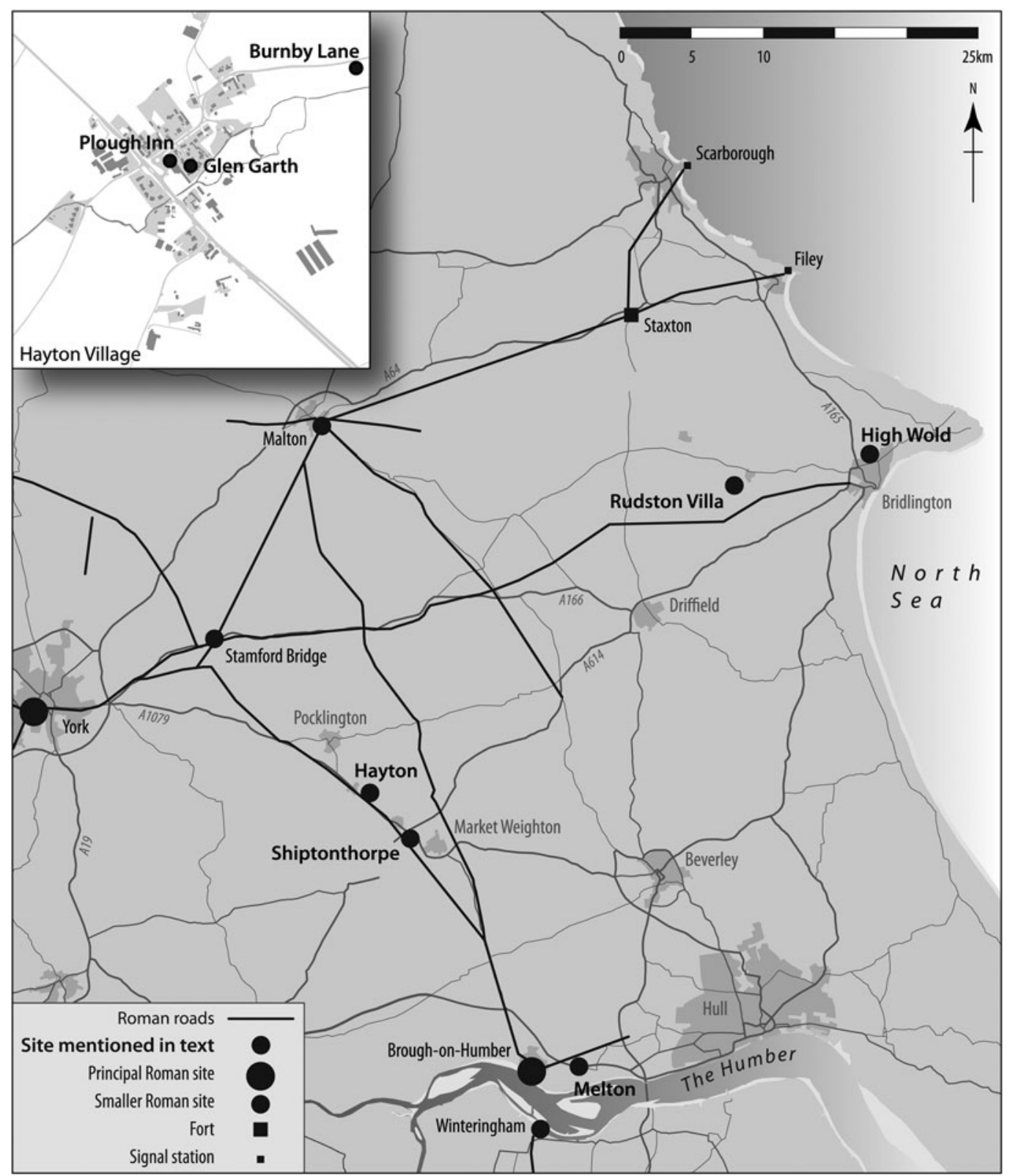

FIG. 2. Map showing the location of the sites in East Yorkshire and at Hayton mentioned in the text. (Drawn by Lacey M. Wallace)

Trench 3 suggested a careful pattern of burial. The rite was a simple one with each burial contained in a small pit in a domestic context, but there was a clear spatial pattern evident (FIG. 4). The eight burials in Trench 3 that could be aged were around 38-40 gestational weeks and there was a main cluster (of seven individuals) around the eastern end of the main domestic building excavated 
(Structure 3.3), plus one beneath its main hearth, one just outside the wall to the south, and two others beside its northern extension (Phase 5) in the vicinity of a waterhole. It was concluded that this represented a specific burial rite reserved for those who died around the time of birth. ${ }^{28}$

TABLE 1. SUMMARY OF THE BURIALS FROM SHIPTONTHORPE

Age

$<26$ gestational weeks

26-28.9 gestational weeks

29-31.9 gestational weeks

32-34.9 gestational weeks

35-37.9 gestational weeks

38-40.9 gestational weeks

41-43.9 gestational weeks

44-46.9 gestational weeks

$>47$ gestational weeks

Uncertain (infants)

9-12 months after birth

Child

Adult

Total

Shiptonthorpe
inhumations
0
0
0
0
0
14
1
0
0
7
0
0
2
$\mathbf{2 4}$

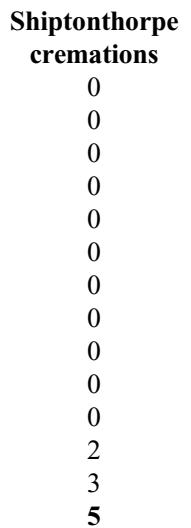

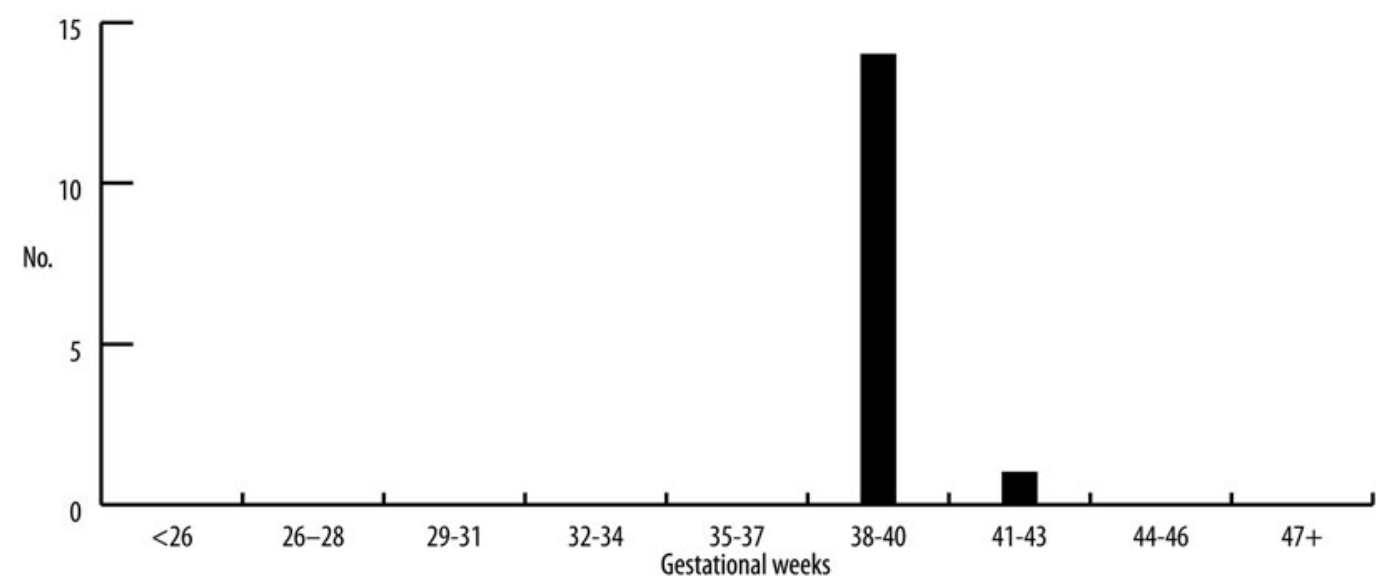

FIG. 3. Age-at-death of infant burials from Shiptonthorpe (data from Table 1). (Drawn by Lacey M. Wallace)

\section{PATTERNS IN THE EVIDENCE: HAYTON — AGE-AT-DEATH}

Following on from the work at Shiptonthorpe, the excavations on the site at Burnby Lane within the landscape project at Hayton, initiated in 1995, paid particular attention to the issue of infant burial, with care taken over their on-site identification and recording. ${ }^{29}$ Additional evidence

Halkon et al. in press. 


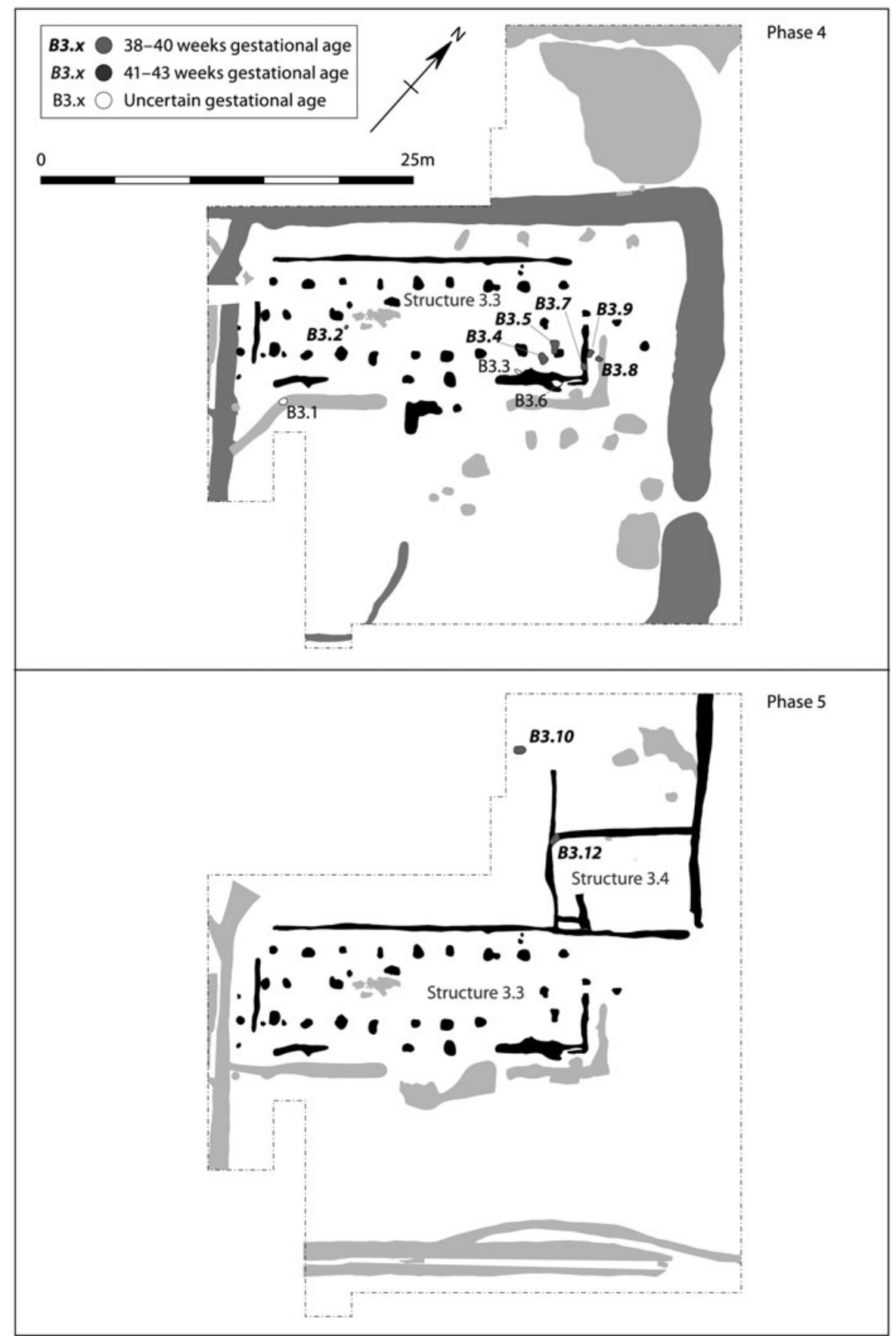

FIG. 4. Plans of Shiptonthorpe Trench 3 showing the location of the infant burials in site Phases 4 and 5 (fourth century A.D.). (B = Burial) (Drawn by Lacey M. Wallace) 
about Roman-period burial in the Hayton study area was subsequently provided by work near by at two other sites, Glen Garth excavated by MAP in 2002 and at the adjacent Plough Inn excavated by Humber Field Archaeology in 2006, although the circumstances of these excavations were far from ideal (FIG. 2). ${ }^{30}$ The human remains from the Burnby Lane site were studied by J. Langston and R. Gowland, while those from Glen Garth and the Plough Inn were recorded by J. Higgins and V.J. Wastling respectively. 31

The Burnby Lane excavation investigated a domestic site which dated from the mid-late Iron Age through to the fourth century and produced burials of 52 people, of whom 41 were infants. There were 43 individuals, including only four infants, from the adjacent sites at Glen Garth/ Plough Inn, which included a formal cemetery used from the late Roman period into the early Middle Ages. Three of these infants (two premature and one a few months old) came from a domestic enclosure, and only one (of uncertain age) came from the cemetery. The age distribution of all the Hayton burials is shown in Table 2 and FIG. 5. The Burnby Lane evidence shows a very strong emphasis on infants aged 38-40 gestational weeks, but with a broader representation of ages than seen at Shiptonthorpe. By contrast the Glen Garth/Plough Inn evidence shows an age distribution more similar to many other Romano-British cemeteries. It is also notable that neonatal infants (aged 38-40 gestational weeks) are absent from these sites, although younger individuals were found. This is perhaps a function of the nature of the Glen Garth settlement excavation, which was undertaken under exceptionally difficult conditions. As has been noted in an earlier publication, ${ }^{32}$ the high recovery of infant burials in the excavations at Shiptonthorpe and Burnby Lane is partially a result of an excavation strategy which involved digging all features initially classified as post-holes. Such sampling is rarely possible on commercial projects for obvious reasons of time pressure.

What we see in the contrast in age distribution between the domestic context at Burnby Lane and the formal cemetery at Glen Garth/Plough Inn is evidence for the differentiation of burial context by age-at-death. It seems clear from this that neonatal infants were normally buried in a domestic context, and that adults were generally placed in a separate formal cemetery. The pattern for pre-full-term infants and older infants/children is less clearly seen, partly because of a lack of evidence, which might itself suggest that such children were generally buried in a different context which we have yet to discover.

In relation to this, it is worth considering a group of three cremation burials found on the Burnby Lane site. ${ }^{33}$ The two better-preserved urns both contained double burials, each with an adult female interred together with a child (aged respectively 2-4 and 6-8 years). Two similar cremation burials contained within urns that were found at Shiptonthorpe also held multiple burials: Cremation 1.1, two adults, one possible male, plus a child; Cremation 1.2 adult plus child. ${ }^{34}$ Neither child could be aged. These graves perhaps support the idea that children were given a different burial rite to infants on the one hand and adults on the other.

The spatial distribution of burials at Burnby Lane, Hayton will be considered below but we may note that both here and at Shiptonthorpe, these cremation burials were found tightly clustered within the settlement, close to, but just outside, occupied domestic enclosures (FIG. 8). Although the numbers are small, it is difficult to believe that this pattern of multiple individuals in single graves plus the association of an adult (or in one case two adults) with a child can be

30 ibid., ch. 20 .

31 Ages at death for the infants were calculated using the regression formulae of Scheuer et al. (1980) on complete long-bone diaphyseal measurements. The dentition was also examined, following the method of Moorrees et al. (1963) for dental development and Ubelaker (1989) for dental eruption.

32 Millett 2007.

33 There were also two cremation burials from the Glen Garth site (Halkon et al. in press, ch. 20) but these were not analysed in the MAP project.

Millett 2006, 256-7. 
TABLE 2. AGE RANGES OF ROMAN HUMAN BURIALS FROM HAYTON

Age

$<26$ gestational weeks 26-28.9 gestational weeks 29-31.9 gestational weeks 32-34.9 gestational weeks 35-37.9 gestational weeks 38-40.9 gestational weeks 41-43.9 gestational weeks 44- 46.9 gestational weeks $>47$ gestational weeks

Infant

Uncertain (infants)

Younger child

Older child

Adolescent

Adult (unknown age)

Young adult

Young/middle adult

Middle adult

Mature adult

Mature/old adult

Total

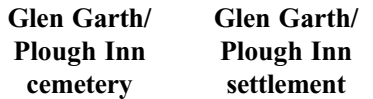

settlement
Burnby Lane
inhumations

0

0

0

0

0

0

0

0

0

1

0

2

4

2

8

4

9

5

4

1

40

\section{Burnby Lane} cremations

Total

Total percent

1
0
1
0
4
25
2
0
0
1
7
0
0
0
2
1
2
0
0
0
46

1.1

0

1.1

1.1

5.3

26.3

2.1

0

0

3.2

7.4

4.2

4.2

2.1

11.6

8.4

11.6

5.3

4.2

1.1

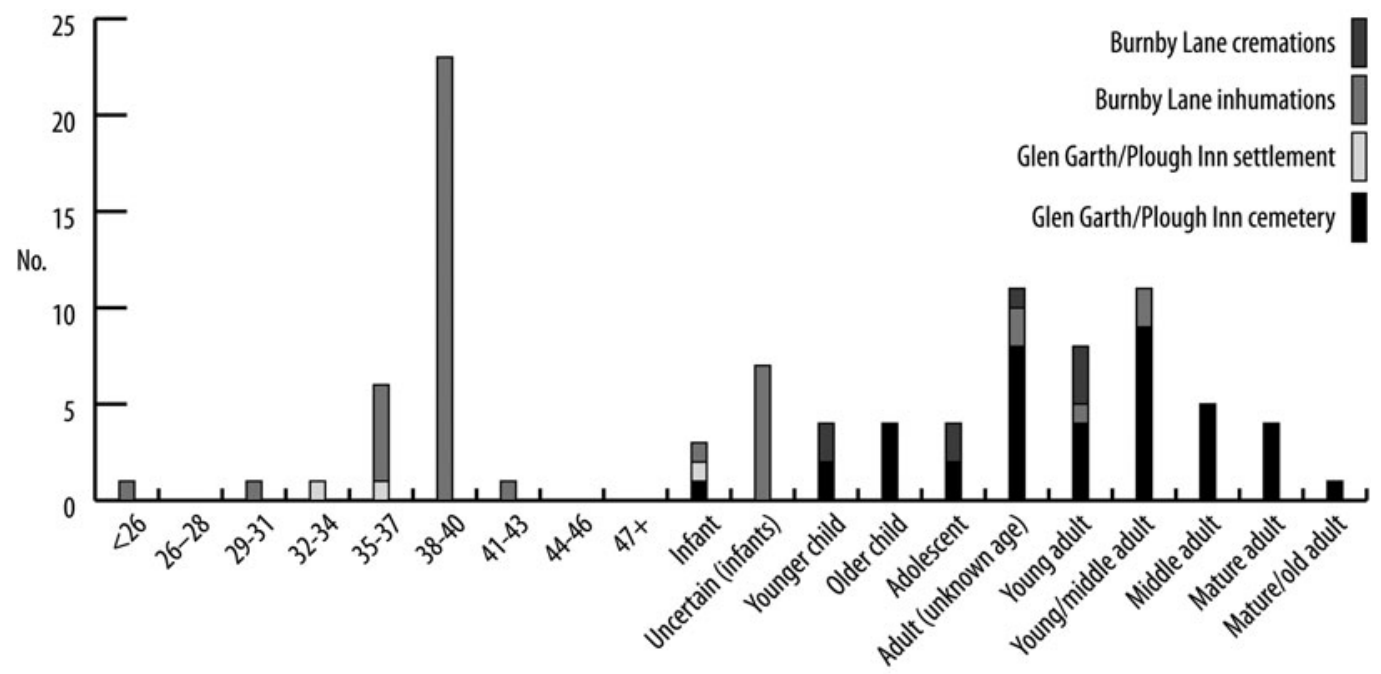

Gestational weeks and age groups

FIG. 5. Age-at-death of burials from Hayton (data from Table 2). (Drawn by Lacey M. Wallace)

the product of chance. Furthermore, it seems improbable that each pair of people died at the same time - unless the cremation rite was reserved for such occasions. Its repetition suggests that one of the dead had been kept, either as a body, or as cremated remains, until the death of an appropriate burial partner. In this context it is notable that at Burnby Lane the pottery vessel 
that contained one of these paired burials was itself unusually old when deposited. It is perhaps more likely that it was a child's body that was curated in this way, until the death of a parent (or, in one case, perhaps both). It remains unclear whether the first death was immediately followed by the cremation of the body, or whether it was kept and then cremated at the same time as the accompanying person. In either case, such curation of human remains has considerable implications for the general representation of different age cohorts. It also raises the question of whether cremation itself was a rite that was universally adopted in this area, as is usually assumed, or one that was confined to particular social circumstances. These questions certainly deserve further research as new evidence is discovered in the future. If such a pattern of burial was more widespread in Roman Britain this would have significant implications. It suggests, for instance, that the widespread assumption that any woman found buried together with an infant had died in childbirth needs re-evaluation.

\section{PATTERNS IN THE EVIDENCE: HAYTON — BURIAL LOCATION}

In contrast to the evidence from Shiptonthorpe the associations between infant burials and excavated structures at Burnby Lane are more complex, partly because of the more fragmentary nature of the structural evidence and partly because of the site's complex sequence. However, despite some uncertainty in the phasing of individual burials, there is again strong evidence for a pattern of careful deposition of neonatal infants within a domestic context, close to occupied buildings. Furthermore, given the longer sequence than at Shiptonthorpe, it is possible to examine the evidence chronologically.

In the late Iron Age phases (FIG. 6), there is a cluster of infant burials in the western enclosure (Enclosure 2.1) to the east of the main domestic roundhouse, with another burial inside the door of the primary structure (Roundhouse 2.1). Those to the east were all aged around full-term (38-40 weeks), while the infant beside the door was slightly younger $(37+$ weeks). There were also two adult burials of this period. A female was buried in Iron Age tradition, laid in a flexed posture on her left side and facing east, in the south-eastern corner of the same settlement enclosure (Burial 2.1) and an isolated adult skull (Burial 2.9), also probably female, was found just to the south-east of the roundhouse. This suggests a pattern of gendering of the domestic space marked by female and infant burials in the eastern part of this enclosure which echoes that noted at Shiptonthorpe. A further three infant burials (the two for which an age estimate was possible being 38-40 weeks) were found in the ditch and gully which mark the boundaries of the adjacent enclosure to the east along with an adult human skull (Burial 2.6) found near by on the eastern boundary. The location of these burials on the enclosure boundaries also indicates a careful pattern, again with a focus on the eastern side. However, in contrast to the western enclosure, these burials were not associated with the roundhouses, which in this part of the site do not seem to have served a domestic purpose. The evidence from this phase demonstrates that the careful burial of full-term infants close to the domestic sphere was a tradition that was already firmly established here during the later Iron Age.

In the early to mid-Roman period (FIG. 7), six infant burials (all that were aged being around full-term, 38-40 weeks) were clustered in a single area at the northern end of a major domestic building (Building 3.1), both within the structure and in the yard immediately outside. An older infant (Burial 3.31), aged 9-12 months, was found further south in the courtyard of this building, and a further isolated infant burial of uncertain age was located within Enclosure 3.3A further to the east. This again shows a strong spatial clustering of neonatal infant burials in a domestic context, but without any evidence for a preference for the eastern end of the building as seen elsewhere. The layout of Building 3.1 is not certain, but the clustering does appear to be associated with its northern wing. 


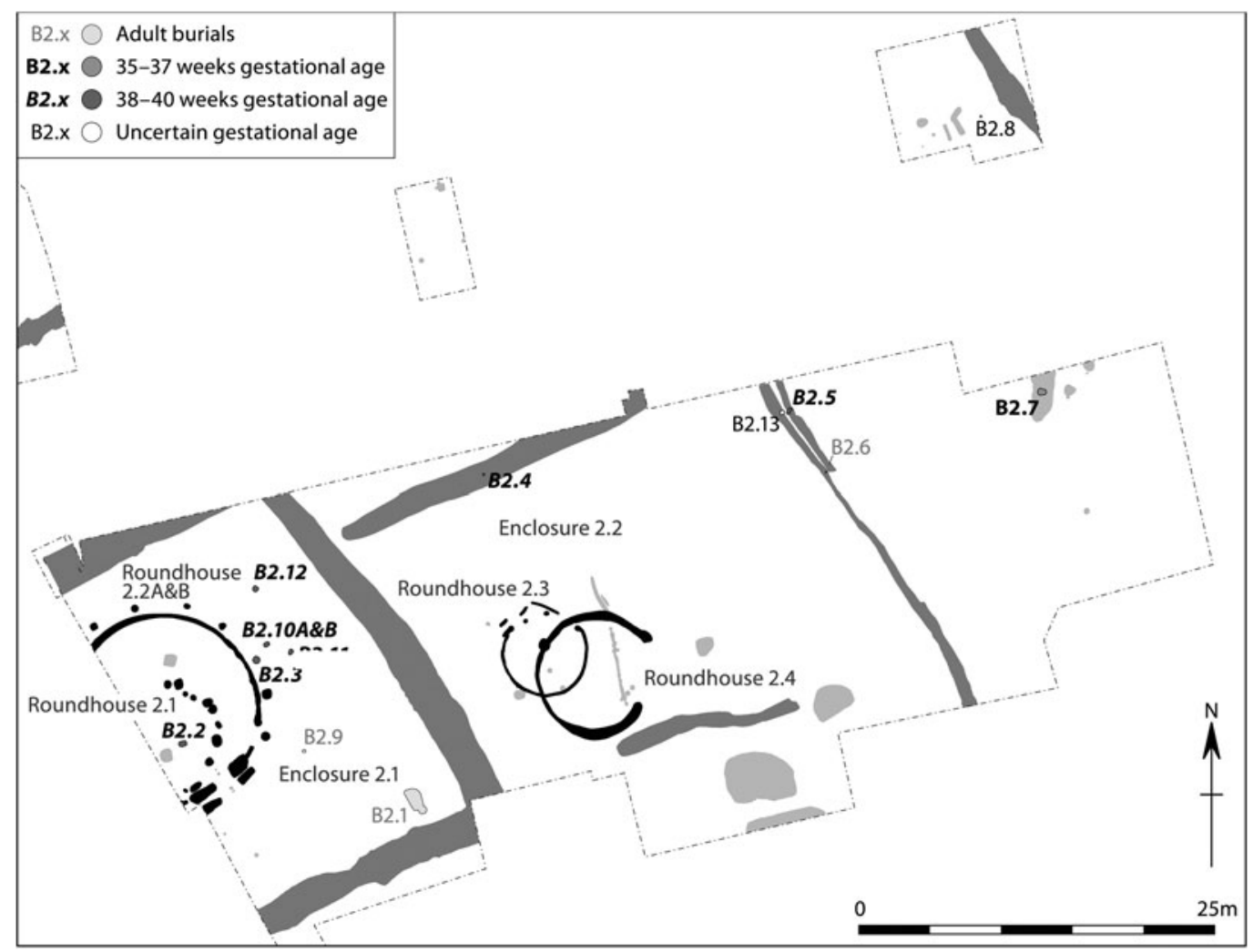

FIG. 6. The distribution of Iron Age-early Roman burials at Burnby Lane (site Periods 2.1 and 2.2: mid/late Iron Age to early second century A.D.). (B = Burial) (Drawn by Lacey M. Wallace, based on plan by Helen Woodhouse)

In the mid-Roman period (FIG. 8), there are two clusters of infant burials. A group of four individuals (three aged 38-40 weeks, the other 41-43 weeks) lay near to those of the preceding period to the east of the Building 3.1, and immediately to the south of the bath-house. There is probably a mixture of factors accounting for this pattern, combining the tradition of burial in this zone with proximity to the new structures. The second group of four (three aged 38-40 weeks, the other of uncertain age) was located to the east of another domestic building (3.2) within the eastern enclosure and on its boundary (Ditch 3.7 and Enclosure Ditch 3.3). These two clusters seem to indicate a recurrence of a preference for easterly locations. There was also a group of cremation burials of this period interred to the north-west, near a then-disused boundary ditch (see above).

In the later Roman period (FIG. 9), the infant burials were more dispersed, with three in the vicinity of the bath-house - under its northern extension, in the yard to its north, and in the area to its south; all continuing earlier locational patterns. One was aged 41-43 weeks, but the other two, perhaps significantly, were less than full-term, perhaps hinting at a different pattern associated with the baths. (An extended male adult burial, Burial 4.40, was also found to the north of the bath-house, but this may date to after its demolition.) The seven other infant burials of this period were found around the walls of the eastern part of a poorly surviving stone building (4.5) which was probably domestic, and were found both to its east and along 


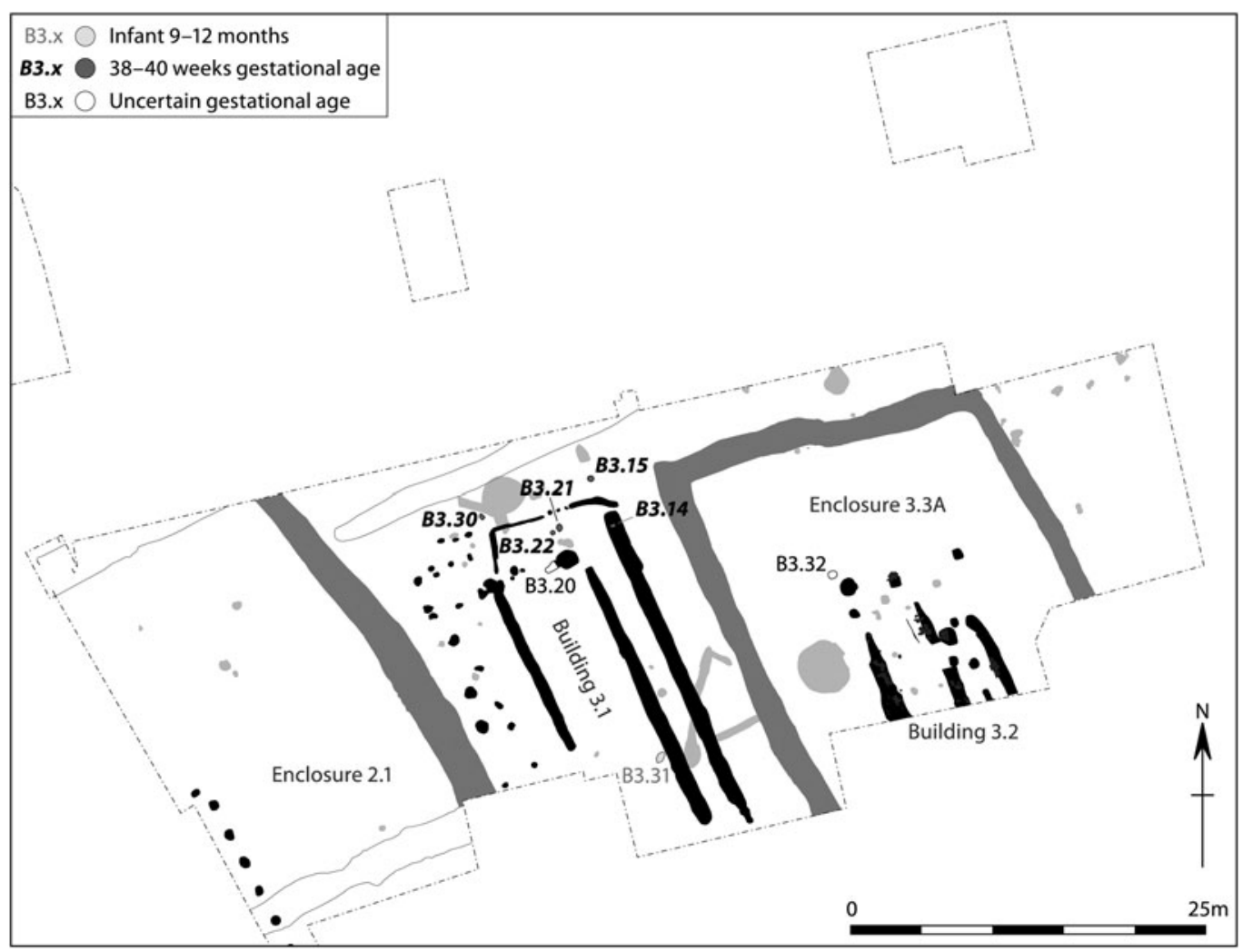

FIG. 7. The distribution of early-mid-Roman burials at Burnby Lane (site Period 3.1: second century A.D.). (B = Burial) (Drawn by Lacey M. Wallace, based on plan by Helen Woodhouse)

its south side. Of the six that can be aged, one was aged 37 weeks, the others $38-40$ weeks, continuing the previous rite of selective burial. There was also an isolated find of an adult skull from this period (Burial 4.39).

In summary, at Burnby Lane there seems to be a strong clustering of neonatal infant burials that implies that their interment was governed by social rules. Taken with the contemporary evidence from Shiptonthorpe, we can see a pattern of their burial close to domestic buildings, with some apparent preference for the eastern side. This perhaps implies a gendering of space within these buildings with the eastern side associated with women and with childbirth as discussed by Scott. ${ }^{35}$ The other obvious pattern for the burial of full-term infants shows an association with boundary locations around domestic habitations, where there is again a preference for locations to the east and also perhaps to the north. There is little to imply any chronological change in rules governing spatial patterning, although there is perhaps evidence that the strength of clustering weakened through time. In general premature infants and those who died after birth are less well represented in the evidence and we would suggest that they were subject to different social rules with their burial probably taking place in other locations. There is slight evidence that we may be 


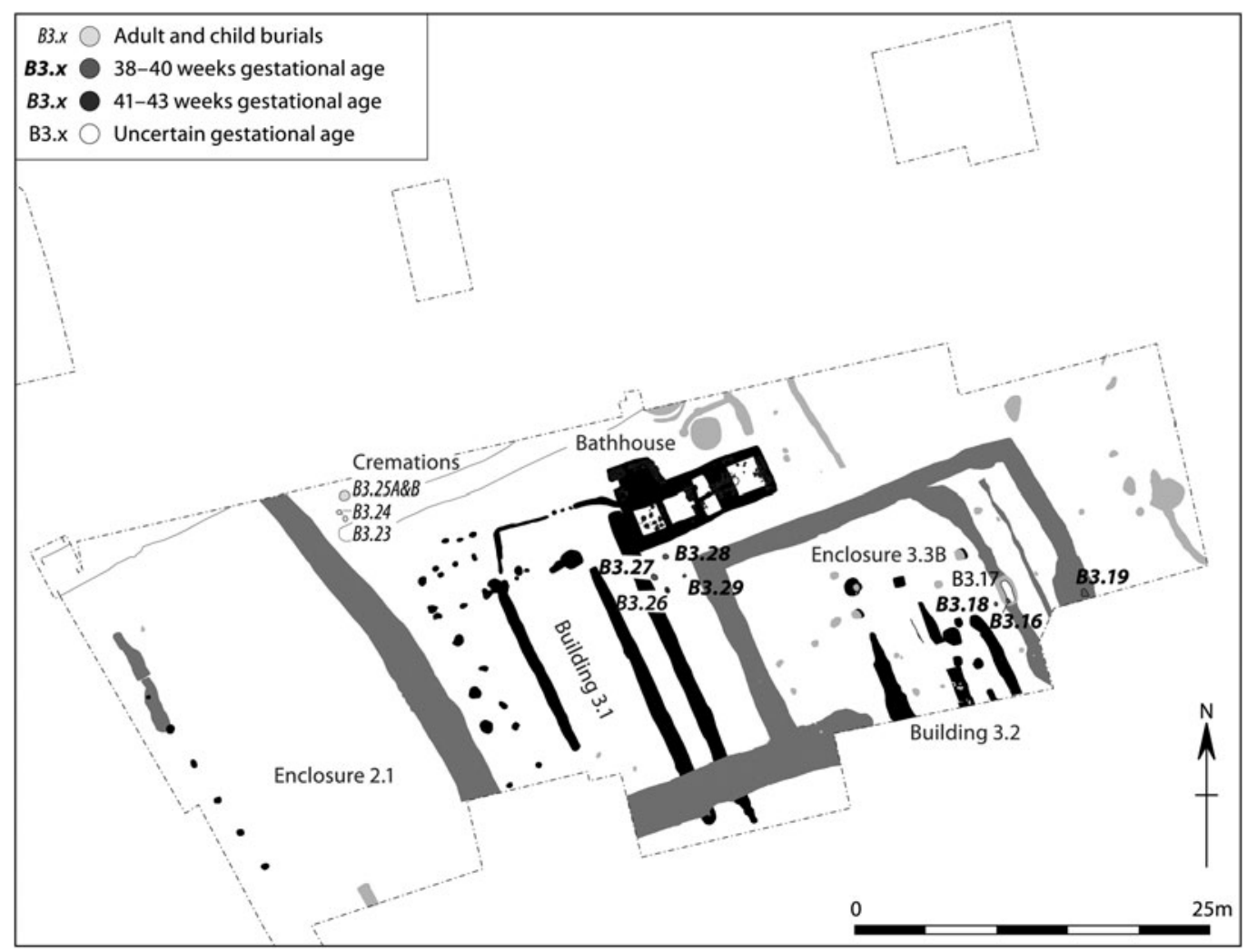

FIG. 8. The distribution of mid-Roman burials at Burnby Lane (site Period 3.2: third to early fourth century A.D.). (B = Burial) (Drawn by Lacey M. Wallace, based on plan by Helen Woodhouse)

seeing some location and ritual patterning in these groups; first with the cluster of premature infants around the bath-house in the later Roman phase, and secondly with the burial of the cremated remains of some children together with adults at both Burnby Lane and Shiptonthorpe.

\section{PATTERNS IN THE EVIDENCE: HAYTON — BURIAL RITUAL}

Although there is clear evidence from the Burnby Lane excavation for the very careful location of infant burials, the evidence does not reveal any discernible preference for their orientation, or the side upon which they were laid. We also lack unambiguous evidence for the presence of grave goods (with occasional objects included being most likely the result of casual inclusion of refuse within grave fills). In one case, an infant was carefully placed in the grave underneath an imbrex tile, in another a tegula was used. Otherwise, burials were made in small pits without archaeologically detectable ceremonial, presumably indicating that they were wrapped in cloth.

Intriguingly the Burnby Lane site also produced an unusually large number of animal burials, including a substantial number of deposits that seem to have been associated with communal feasting on lambs and sheep. Analysis of these deposits suggests that they were the product of 


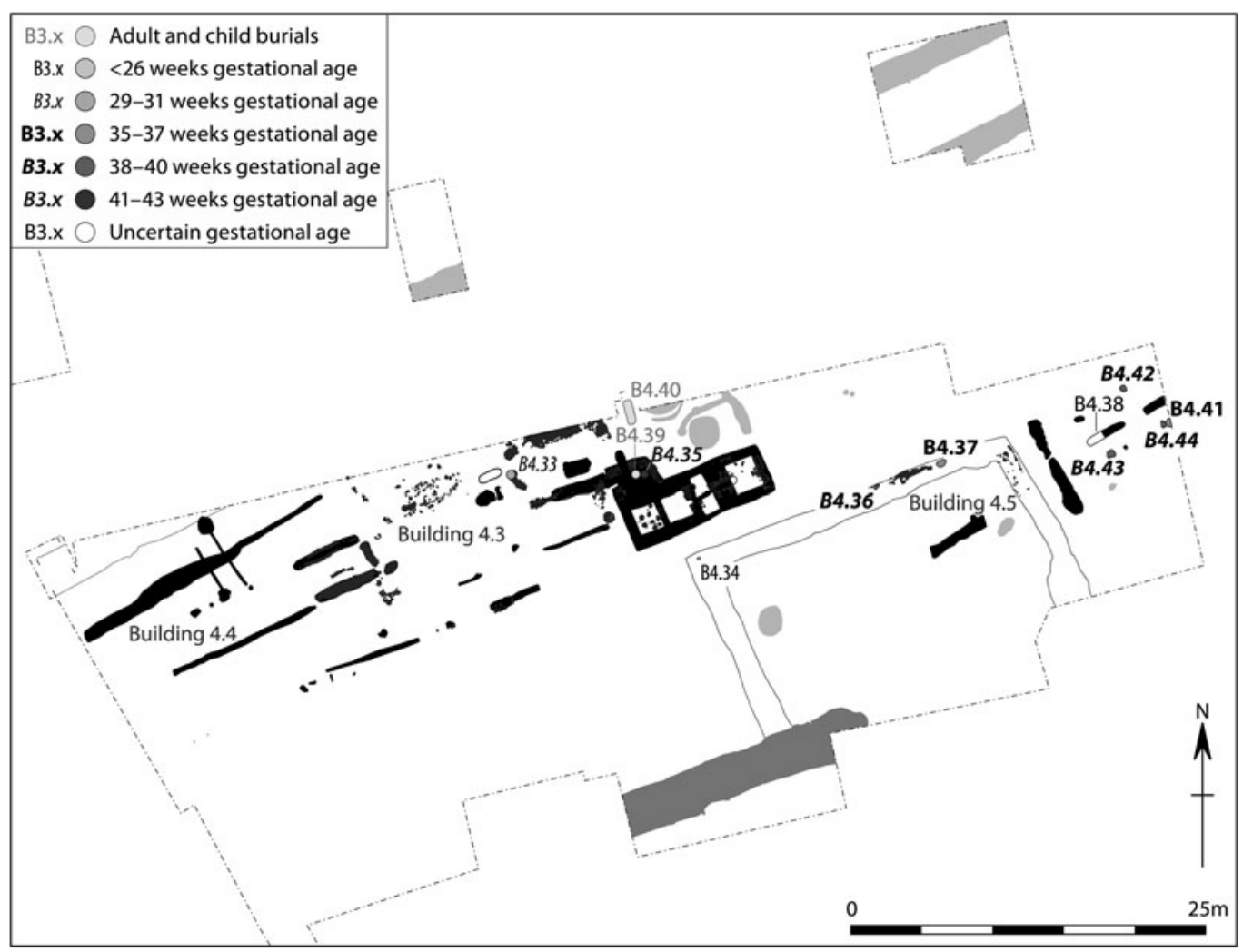

FIG. 9. The distribution of later Roman burials at Burnby Lane (site Period 4: mid to later fourth century A.D.). (B = Burial) (Drawn by Lacey M. Wallace, based on plan by Helen Woodhouse)

celebrations marking stages within the human life-cycle. ${ }^{36}$ Given the general spatial association of these feasting deposits with human burials on the site, it may be that there were funerary feasts held at the burial of these infants. If so, this would reinforce the suggestion that they were buried with ceremony according to clear social rules and not simply 'disposed of' as is sometimes implied. Scott has also highlighted the high frequency of animal bones associated with infant burials at villa sites, which she interprets as having votive significance. ${ }^{37}$

\section{GENERAL DISCUSSION}

The evidence from Hayton and Shiptonthorpe corresponds with patterns of infant burials observed near by ${ }^{38}$ and elsewhere in Roman Britain. In discussing the infant burials from domestic contexts

\footnotetext{
36 Halkon et al. in press, chs 17 and 21.

Scott 1991.

A large group of infant burials (58 in total) was excavated at the Roman roadside settlement at Rudstone Dale, near Cave in East Yorkshire, by Network Archaeology (Mike Wood pers. comm.) but we do not have details of their age profile or exact contexts.
} 
at High Wold Bridlington, Roberts has drawn attention to others from the region ${ }^{39}$ to which we may now add those from beside a boundary at Melton. ${ }^{40}$ These frequently demonstrate the careful location of neonatal infant burials in the domestic sphere. It is also clear from the contextual evidence that such burials are contemporaneous with the habitation of these dwellings. For example, at Winterton, Lincs., three infant burials were sealed between successive floor layers, ${ }^{41}$ and at Bradley Hill, Somerset, the infant burials were overlain by occupation debris. ${ }^{42}$

The infant burials at Hayton, along with those observed elsewhere, are not haphazard, but are specifically placed adjacent to features and walls. The burials within buildings are often located in the corners of rooms, which may represent spatially the liminal status of these infants. Examples include all seven of the infant burials from Bucknowle Farm Villa which are located in the corners of adjacent rooms; ${ }^{43}$ at Catsgore four of the five infant burials within the building were located in the corners of the room, ${ }^{44}$ and at Stanton Low all four infant burials were located in corners. ${ }^{45}$ A number of infant burials have also been recovered from outbuildings and workshop areas, as seen with certain of the burials from non-domestic features in the late Iron Age phase of Hayton. For example, at Rudston Roman Villa, Yorks., several of the buildings with infant burials contained hearths and corn-drying kilns and were described as workshops. ${ }^{46}$ At Littlecote Park Villa, Wilts., of the five infant burials, two were associated with domestic rooms and three were associated with a bronze-working furnace. ${ }^{47}$ At both Catsgore and Bradley Hill, Somerton, infants had been buried in dwelling houses and out-buildings. ${ }^{48}$ Scott highlights an association between infant burials and contexts interpreted as corn-driers at sites such as Yewden and Barton Court Farm, Oxon. She interprets this in terms of the gendering of domestic and agricultural space, potentially symbolising a link between fertility and agricultural production. ${ }^{49}$ Moore also concludes that the burial of infants was 'not the random disposal of the unwanted or marginalised, but the result of careful choices and decisions'. ${ }^{50}$ The evidence from Hayton and Shiptonthorpe supports her observations about the association between infant burials and both liminal locations and hearths.

One of the over-riding impressions from the spatial distribution of these infant burials is the consistent desire to maintain a physical and symbolic connection between the mother (or family) and infant. In Western discourse we consider bodies to be discrete, bounded entities, and life courses to be, likewise, separate, linear, biographies. This is not a universal viewpoint and many cultures view life courses to be inter-connected and cyclical, and bodies to be 'partible'. ${ }^{51}$ It could be argued from the evidence discussed above that infants in Iron Age and Roman Britain were not considered to be separate entities and instead were an indivisible part of the mother. This is a concept that has been observed ethnographically, with abortion for some cultures considered a form of self-mutilation because the foetus is not seen to be separate from the mother. ${ }^{52}$ In the Western world, where the developing foetus and mother have been

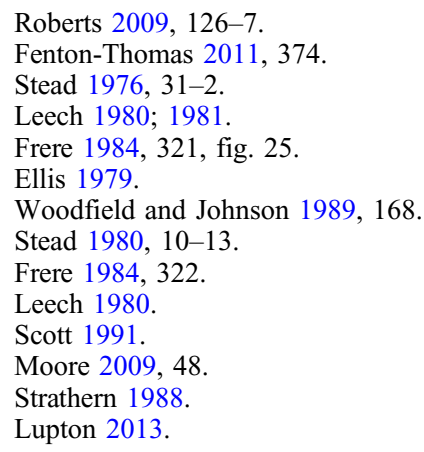


increasingly conceptualised as distinct, some women even in late pregnancy have difficulty conceiving of the foetus as separate from themselves. ${ }^{53}$ Cross-culturally it has been observed that the mother does not just figuratively 'lose a part of herself' with the death of her newborn, but does so in a very literal sense. The pattern of burial signals an unease with the complete severance of this connection between mother and infant and an apparent need to sustain this link through proximity between the living and the dead. This may also explain the cremated burials of adult females at Hayton within the domestic sphere - perhaps the females in these instances were survived by their infants and this connection still needed to be maintained after the mother's death, i.e. the same pattern in reverse. Another example of this is observed at Rudston Roman Villa where a young adult female is also buried in the vicinity of a building with infant burials. ${ }^{54}$

Although we should be cautious about using literary evidence from the centre of the Empire in the context of understanding Roman Britain, the 'otherness' of infants in the Roman world is attested in historical texts. The physiology of an infant's body was considered distinct from older children and adults; it was conceptualised as still 'wet' and wax-like. 55 According to Pliny and Juvenal a child was not considered to be a separate individual until the second half of the first year, once teething and possibly walking and talking had commenced. ${ }^{56}$ Pliny explained that children who had not teethed were not cremated (the predominant rite at that time) and that intra-mural burial, particularly under the eaves of buildings, while forbidden by law for older individuals, was customary for young infants. ${ }^{57}$ Pearce notes that the transition from inhumation to cremation from approximately six months of age is documented in a number of cemeteries from the Roman provinces ${ }^{58}$ and the later age of cremation appears to be borne out by the data at Hayton and Shiptonthorpe. Overall, however, he highlights that the age categorisations identified through differentiation in burial practice do not correspond with the general constructs for Roman society as indicated by the textual sources. ${ }^{59}$ Age-related burial practices in Roman Britain and the periphery of the Empire are likely to have evolved out of local traditions, as indicated at Hayton, and are unlikely to faithfully replicate age norms from the core of the Empire in Italy. The special status of the newborn infant is enacted repeatedly in the funerary rite from Roman Britain. The liminal status is attested in the location of the infant next to boundaries, most notably walls, or sites of transformation, such as hearths or agricultural features. The indivisibility of the mother/infant entity is performed through the proximity of the infant to the domestic space.

\section{CONCLUSIONS}

The evidence presented in this paper demonstrates that the burial of infants at these two sites was not a product of careless disposal, and far less does it provide any evidence to suggest that infanticide was practised. Rather it shows that different social groups within the population, certainly defined by age and probably by other aspects of social identity too, were afforded burial according to social norms, which meant that they were not all buried in the same location or in the same manner. While it does not wholly resolve the problem of understanding the social rules which governed burial in this area during the period, it does go some way

ibid.

Stead 1980, 146-7, fig. 8.

Dasen 2011.

Pliny, Naturalis Historia 7.15; Juvenal, Saturae 15.139.

Watts 1989; Philpott 1991, 97-101.

Pearce 2001, 136-7.

ibid., 128. 
towards it. It highlights that the careful burial of infants has its origins in the pre-Roman Iron Age. Similarly, it shows that neonatal infants were closely associated with the domestic sphere. The entrenching of deceased infants firmly within the social sphere of the living, implicates their continued social agency and provides insights into understandings of the mother/infant dyad. We would not pretend that our conclusions should be applied universally, but rather would expect social norms to vary with space and time across Britain and the Roman world. We would thus contend that we have evidence for social practice in this region and that comparable patterns should be sought through a very careful examination of the evidence from other areas. We trust that this evidence disposes once and for all with the suggestion that infanticide was the norm in Roman Britain.

\section{ACKNOWLEDGEMENTS}

Thanks go to all those who participated in and supported the excavations at Shiptonthorpe and Hayton, and especially those who contributed to the excavation reports drawn on here. A previous version of this paper was presented at a conference organised by Belinda Crerar and held at the Faculty of Classics, Cambridge in April 2012. We are grateful to the participants in that conference and to two anonymous readers who have helped us sharpen our arguments.

Faculty of Classics, University of Cambridge (MM)

mjm62@cam.ac.uk

Department of Archaeology, Durham University (RG)

rebecca.gowland@durham.ac.uk

\section{BIBLIOGRAPHY}

Aubet, M.E. 1993: The Phoenicians in the West, Cambridge

Boswell, J.E. 1984: 'Expositio and oblation: the abandonment of children and the ancient and medieval family', American Historical Review 89, 10-33

Boswell, J.E. 1998: The Kindness of Strangers: the Abandonment of Children in Western Europe from Late Antiquity to the Renaissance, Chicago

Buckberry, J. 2000: 'Missing presumed buried? Bone diagenesis and the under-representation of Anglo-Saxon children', Assemblage 5 (http://www.assemblage.group.shef.ac.uk/5/buckberr.html)

Cocks, A.H. 1921: 'A Romano-British homestead in the Hambleden Valley', Archaeologia 71, 141-98

Crawley-Quinn, J. 2011: 'The cultures of the Tophet', in E.S. Gruen (ed.), Cultural Identity in the Ancient Mediterranean, Los Angeles, 388-413

Dasen, V. 2011: 'Childbirth and infancy in Greek and Roman antiquity', in B. Rawson (ed.), Companion to Families in the Greek and Roman Worlds, Oxford, 291-314

Davies, D., Gardner, A., and Lockyear, K. (eds) 2001: TRAC 2000: Proceedings of the Tenth Annual Theoretical Roman Archaeology Conference, London 2000, Oxford

Ellis, P. 1979: Catsgore: Further Excavation of the Romano-British Village, Western Archaeological Trust Excavation Monograph 7, Stroud

Eyers, J.E. (ed.) 2011: Romans in the Hambledon Valley: Yewden Roman Villa, Chiltern Archaeology Monograph 1, High Wycombe

Faerman, M., Kahila, G., Smith, P., Greenblatt, C., Stager, L., Filon, D., and Oppenheim, A. 1997: 'DNA analysis reveals sex of infanticide victims', Nature 385, 212-13

Farwell, D.E., and Molleson, T.I. 1993: Poundbury Volume 2. The Cemeteries, Dorset Natural History and Archaeological Society Monograph Series 11, Dorchester

Fenton-Thomas, C. 2011: Where Sky and Yorkshire and Water Meet: the Story of the Melton Landscape from Prehistory to the Present, On-site Archaeology Monograph 2, York 
Frere, S.S. 1984: 'Roman Britain in 1983', Britannia 15, 266-332

Gowland, R. 2001: 'Playing dead: implications of mortuary evidence for the social construction of childhood in Roman Britain', in Davies et al. 2001, 152-68

Gowland, R.L., and Chamberlain, A.T. 2002: 'A Bayesian approach to ageing perinatal skeletal material from archaeological sites: implications for the evidence for infanticide in Roman Britain', Journal of Archaeological Science 29, 677-85

Gowland, R.L., Chamberlain, A.T., and Redfern, R.C. 2014: 'On the brink of being: re-evaluating infant death and infanticide in Roman Britain', in M. Carroll and E.-J. Graham (eds), Infant Health and Death in Roman Italy and Beyond, Journal of Roman Archaeology Supplementary Series 98, Porstmouth, RI, 69-88

Grubbs, J.E. 2010: 'Hidden in plain sight: Expositi in the community', in V. Dasen and T. Späth (eds), Children, Memory, and Family Identity in Roman Culture, Oxford, 293-310

Guy, H., Masset, C., and Baud, C.-A. 1997: 'Infant taphonomy', International Journal of Osteoarchaeology 7, 221-9

Halkon, P., Millett, M., and Woodhouse, H. (eds) in press [2015]: Hayton, East Yorkshire: Archaeological Studies of the Iron Age and Roman Landscapes, Yorkshire Archaeological Report, Leeds

Hassan, M.A.-B., Brown, K.A., Eyers, J., Brown, T.A., and Mays, S. 2014: 'Ancient DNA study of the remains of putative infanticide victims from the Yewden Roman Villa site at Hambledon, England', Journal of Archaeological Science 43, 192-7

Leech, R. 1980: 'Religion and burials in South Somerset and North Dorset', in W. Rodwell (ed.), Temples, Churches and Religion: Recent Research in Roman Britain, BAR British Series 77(i), Oxford, 329-52

Leech, R. 1981: 'The excavation of a Romano-British farmstead and cemetery on Bradley Hill, Somerton, Somerset', Britannia 12, 177-252

Lupton, A. 2013: The Social Worlds of the Unborn, London

Mays, S. 1993: 'Infanticide in Roman Britain', Antiquity 67, 883-8

Mays, S. 2000: 'The archaeology and history of infanticide, and its occurrence in earlier British populations', in J. Sofaer Derevenski (ed.), Children and Material Culture, London, 180-90

Mays, S. 2003: 'Comment on "A Bayesian approach to ageing perinatal skeletal material from archaeological sites: implications for the evidence for infanticide in Roman Britain" by R.L. Gowland and A. T. Chamberlain', Journal of Archaeological Science 30, 1695-1700

Mays, S., and Eyers, J. 2011: 'Perinatal infant death at the Roman villa site at Hambleden, Buckinghamshire, England', Journal of Archaeological Science 38, 1931-8

Mays, S., and Faerman, M. 2001: 'Sex identification of some putative infanticide victims from Roman Britain using ancient DNA', Journal of Archaeological Science 28, 555-9

Mays, S., Robson-Brown, K., Vincent, S., Eyers, J., King, H., and Roberts, A. 2012: 'An infant femur bearing cut marks from Roman Hambleden, England', International Journal of Osteoarchaeology 24, $111-15$

Millett, M. (ed.) 2006: Shiptonthorpe, East Yorkshire: Archaeological Studies of a Romano-British Roadside Settlement, Yorkshire Archaeological Society Roman Antiquities Section Monograph 5, Leeds

Millett, M. 2007: 'Experiments in the analysis of finds deposition at Shiptonthorpe: a retrospect', in R. Hingley and S.H. Willis (eds), Roman Finds: Context and Theory, Oxford, 100-5

Moore, A. 2009: 'Hearth and home: the burial of infants within Romano-British domestic contexts', Childhood in the Past 2, 33-54

Moorrees, C.F.A., Fanning, E.A., and Hunt, E.F. 1963: 'Formation and resorption of three deciduous teeth in children', American Journal of Physical Anthropology 21, 205-13

Pearce, J. 2001: 'Infants, cemeteries and communities in the Roman provinces', in Davies et al. 2001, 125-42

Pearce, J. 2013: Contextual Archaeology of Burial Practice: Case Studies from Roman Britain, BAR British Series 588, Oxford

Pearce, J., Millett, M., and Struck, M. (eds) 2001: Burial, Society and Context in the Roman World, Oxford

Philpott, R. 1991: Burial Practices in Roman Britain, BAR British Series 219, Oxford

Roberts, I. 2009: 'A late Iron Age and Romano-British settlement at High Wold, Bempton Lane, Bridlington, East Yorks', Yorkshire Archaeological Journal 81, 47-137

Scheuer, J.L., Musgrave, J.H., and Evans, S.P. 1980: 'Estimation of late foetal and perinatal age from limb bone length by linear and logarithmic regression', Annals of Human Biology 7, 257-65 
Scott, E. 1991: 'Animal and infant burial in Romano-British villas: a revitalization movement', in P. Garwood, D. Jennings, R. Skeates and J. Toms (eds), Sacred and Profane, Oxford University Committee for Archaeology Monograph 32, Oxford, 115-21

Scott, E. 1997: 'On the incompleteness of archaeological narratives', in J. Moore and E. Scott (eds), Invisible People and Processes: Writing Gender and Childhood into European Archaeology, London, 1-12

Scott, E. 1999: The Archaeology of Infancy, BAR International Series 819, Oxford

Scott, E. 2001: 'Unpicking a myth: the infanticide of female and disabled infants in antiquity', in Davies et al. 2001, 143-51

Smith, P., and Kahila, G. 1992: 'Identification of infanticide in archaeological sites: a case study from the late Roman Byzantine periods at Ashkelon, Israel', Journal of Archaeological Science 19, 667-75

Stager, L.E., Schloen, J.D., and Master, D.M. (eds) 2008: Final Reports of the Leon Levy Expedition to Ashkelon. Ashkelon 1: Introduction and Overview (1985-2006), Indiana

Stead, I.M. 1976: Excavations at Winterton Roman Villa and Other Roman Sites in North Lincolnshire, 1958-1967, London

Stead, I.M. 1980: Rudston Roman Villa, Leeds

Strathern, M. 1988: The Gender of the Gift. Problems with Women and Problems with Society in Melanesia, Berkeley

Struck, M. (ed.) 1993: Römerzeitliche Graber als Quellen zu Religion, Bevölkerungsstruktur und Sozialgeschichte, Mainz

Ubelaker, D.H. 1989: Human Skeletal Remains: Excavation, Analysis and Interpretation, Chicago

Watts, D.J. 1989: 'Infant burials and Romano-British Christianity', Archaeological Journal 146, 372-83

Woodfield, C., and Johnson, C. 1989: 'A Roman site at Stanton Low, on the Great Ouse, Buckinghamshire, excavated by M. Jones 1957-1958', Archaeological Journal 146, 135-278 